\title{
Primary School Classroom Teachers' Attitudes toward Multi-Culture and Multicultural Education in China
}

\author{
Weiju Zhao ${ }^{1}$, Ling Liu ${ }^{2}$ \\ ${ }^{1,2}$ College of Education Science, Nantong University, Nantong, 226019, Jiangsu, China
}

\begin{abstract}
In this paper, we carry out an investigation about 196 Nantong classroom teachers' attitudes toward multi-culture and multicultural education with the questionnaire method. Findings demonstrate that primary school classroom teachers hold positive attitudes toward multi-culture and multicultural education, while some of them are vague even negative. Nonlocal primary school classroom teachers' attitudes are more positive than Nantong local teachers'. Urban primary school classroom teachers' attitudes are more positive than rural school teachers'. Because of the differences of age, education background, teaching years, school position, and local identity, there are different degrees of differences of primary school classroom teachers' attitudes toward multi-culture and multicultural education.
\end{abstract}

Keywords: primary school; classroom teacher; multi-culture; multicultural education; attitude

\section{INTRODUCTION}

Nowadays, with an enormous number of nonlocal individuals working and living in Nantong, Jiangsu province, China, their children are educated in Nantong in succession. The outsiders from different cultural backgrounds and their children, together with the local folks, construct a new culture of Nantong. In this process, there are not only the communication and integration of different cultures, but also the collision and conflicts of cultures. Therefore, it is exceedingly important to understand, recognize, appreciate and accept one's own culture as well as other cultures, pupils are no exception.

As instructional gatekeepers, teachers navigate a complex terrain of societal discourse and expectations, educational policy, and personal beliefs, influencing the manner by which young citizens learn about their roles in multicultural democracies (Banks et al., 2005). Primary school classroom teachers as the leader of a class, their attitudes toward multi-culture are bound to influence pupils' understanding and identification of multi-culture. Similarly, their attitudes toward multicultural education also determine whether they will implement that in daily class management and eventually affect pupils' multicultural literacy. Thus, it is critical to study primary school classroom teachers' attitudes toward multi-culture and multicultural education.

\section{Method}

This paper randomly selected 196 primary school classroom teachers from 8 primary schools (4 urban and 4 rural primary schools) in Nantong, Jiangsu Province, China. The questionnaire is based on Teachers' attitudes toward multicultural education in Macao (Tian, 2002) with 5-Likert scale.

Data analysis was conducted through SPSS statistical package, version 16.0.

\section{RESUltS AND ANALYSIS}

Table1. Information of teachers

\begin{tabular}{|c|c|c|c|c|c|c|}
\hline \multicolumn{6}{|c|}{ 196 Nantong primary school classroom teachers' information. } \\
\hline \multirow{2}{*}{ Category } & \multicolumn{2}{|c|}{ Gender } & \multicolumn{4}{|c|}{ Education background } \\
\cline { 2 - 7 } & Male & Female & $\begin{array}{c}\text { Secondary normal } \\
\text { school }\end{array}$ & Associate & Bachelor & Master \\
\hline Number & 44 & 152 & 39 & 75 & 52 & 30 \\
\hline Percent & $22.4 \%$ & $77.6 \%$ & $19.9 \%$ & $38.3 \%$ & $26.5 \%$ & $15.3 \%$ \\
\hline
\end{tabular}


Weiju Zhao \& Ling Liu

\begin{tabular}{|c|c|c|c|c|c|c|c|c|}
\hline \multirow[t]{2}{*}{ Category } & \multicolumn{2}{|c|}{ Local identity } & \multicolumn{6}{|c|}{ Age } \\
\hline & Local & Nonlocal & $<25$ & $26-35$ & & & $46-55$ & $>55$ \\
\hline Number & 124 & 72 & 33 & 57 & & & 44 & 16 \\
\hline Percent & $63.3 \%$ & $36.7 \%$ & $16.8 \%$ & $29.1 \%$ & & & $22.4 \%$ & $8.2 \%$ \\
\hline \multirow[t]{2}{*}{ Category } & \multicolumn{2}{|c|}{ School position } & \multicolumn{6}{|c|}{ Teaching years } \\
\hline & Urban & Rural & $<2$ & $2-5$ & $6-10$ & $11-15$ & $16-20$ & $>20$ \\
\hline Number & 108 & 88 & 23 & 29 & 34 & 45 & 40 & 25 \\
\hline Percent & $55.1 \%$ & $44.9 \%$ & $11.7 \%$ & $14.8 \%$ & $17.3 \%$ & $23.0 \%$ & $20.4 \%$ & $12.8 \%$ \\
\hline
\end{tabular}

\subsection{Overall Situation of Primary School Classroom Teachers' Attitudes toward Multi-Culture and Multicultural Education}

Table2. Primary school classroom teachers' attitudes toward multi-culture

\begin{tabular}{|c|c|c|c|c|c|}
\hline Item & $\begin{array}{l}\text { Strongly } \\
\text { agree } \\
(\%)\end{array}$ & $\begin{array}{c}\text { Agree } \\
(\%)\end{array}$ & $\begin{array}{l}\text { Neutral } \\
(\%)\end{array}$ & $\begin{array}{l}\text { Disagree } \\
(\%)\end{array}$ & $\begin{array}{l}\text { Strongly } \\
\text { disagree } \\
\quad(\%)\end{array}$ \\
\hline $\begin{array}{l}\text { 1. I like to get along with people from different } \\
\text { cultural backgrounds. }\end{array}$ & 6.6 & 64.8 & 15.8 & 9.2 & 3.6 \\
\hline $\begin{array}{l}\text { 2. People from different cultural backgrounds do } \\
\text { not have much in common. }\end{array}$ & 7.7 & 42.3 & 16.8 & 18.4 & 14.8 \\
\hline $\begin{array}{l}\text { 3. I can learn a lot from groups from different } \\
\text { cultural backgrounds. }\end{array}$ & 21.9 & 37.8 & 6.6 & 33.7 & 0.0 \\
\hline $\begin{array}{l}\text { 4. I have difficulty getting along with people from } \\
\text { different cultural backgrounds. }\end{array}$ & 25.0 & 27.6 & 9.2 & 36.7 & 1.5 \\
\hline $\begin{array}{l}\text { 5. Knowing about the people from different cultural } \\
\text { backgrounds is conducive to understanding the } \\
\text { local society. }\end{array}$ & 41.8 & 40.8 & 2.6 & 14.8 & 0.0 \\
\hline $\begin{array}{l}\text { 6. Freedom of belief is one of the characteristics of } \\
\text { a multicultural society. }\end{array}$ & 17.9 & 56.6 & 10.7 & 14.8 & 0.0 \\
\hline $\begin{array}{l}\text { 7. Outsiders should learn to preserve their own } \\
\text { culture and get along with mainstream society in } \\
\text { harmony. }\end{array}$ & 42.3 & 23.0 & 3.1 & 30.1 & 1.5 \\
\hline $\begin{array}{l}\text { 8. Outsiders should abandon their traditions into } \\
\text { mainstream society. }\end{array}$ & 1.5 & 10.2 & 12.8 & 70.9 & 4.6 \\
\hline $\begin{array}{l}\text { 9. Multicultural society shows the cultural richness } \\
\text { and diversity. }\end{array}$ & 25.5 & 56.1 & 2.6 & 14.8 & 1.0 \\
\hline $\begin{array}{l}\text { 10. Living in a multicultural society requires mutual } \\
\text { respect and tolerance. }\end{array}$ & 24.0 & 64.3 & 4.6 & 7.1 & 0.0 \\
\hline $\begin{array}{l}\text { 11. Living in a monocultural area is better than } \\
\text { living in a multicultural area. }\end{array}$ & 0.0 & 21.9 & 16.3 & 52.6 & 9.2 \\
\hline $\begin{array}{l}\text { 12. Each culture should be recognized and carried } \\
\text { forward in Nantong. }\end{array}$ & 1.5 & 68.4 & 5.6 & 10.2 & 14.3 \\
\hline
\end{tabular}

Table 2 indicates that $71.4 \%$ of primary school classroom teachers are willing to associate with the individuals from different cultural backgrounds, though $52.6 \%$ of teachers consider that is difficult. $59.7 \%$ of teachers maintain that they can attain new knowledge from groups from different cultural backgrounds and more teachers $(82.6 \%)$ reckon that knowing about the people from different cultural backgrounds is conducive to understanding the local society. Half of the primary school classroom teachers realize that people from different cultural backgrounds will not have much in common, $74.5 \%$ of teachers agree that freedom of belief is one of the multicultural character of our society. $81.6 \%$ deem that multicultural society shows the cultural richness of diversity. Nearly $70 \%$ of teachers hold that each culture should be recognized and carried forward in Nantong. Up to $88.3 \%$ of teachers believe living in a multicultural society requires mutual tolerance and respect. Meanwhile, $61.8 \%$ of primary school classroom teachers regard that living in a multicultural area is better than living in a mono-cultural area.

It should be noted that $75.5 \%$ of teachers oppose the outsiders to abandon their traditions into mainstream society; however, only $65.3 \%$ encourage the outsiders to preserve their own culture and get along with mainstream society in harmony. Obviously, $10.2 \%$ of classroom teachers' attitudes toward coexistence of foreign and local cultures and their ways are inconsistent.

Table 2 also presents that the neutral proportions in question $1-12$ are $15.8 \%, 16.8 \%, 6.6 \%, 9.2 \%$, $2.6 \%, 10.7 \%, 3.1 \%, 12.8 \%, 2.6 \%, 4.6 \%, 16.3 \%$ and $5.6 \%$ respectively. 
In addition, $12.8 \%$ of primary school classroom teachers are not willing to getting along with people from different cultural backgrounds. $33.7 \%$ of teachers do not believe they can learn from groups from different cultural backgrounds. $21.9 \%$ of primary school classroom teachers hold that living in a mono-cultural area is better than a multicultural area and $24.5 \%$ do not endorse every culture in Nantong should be recognized and carried forward.

Table3. Primary school classroom teachers' attitudes toward multicultural education

\begin{tabular}{|l|c|c|c|c|c|}
\hline \multicolumn{1}{|c|}{ Item } & $\begin{array}{c}\text { Strongly } \\
\text { agree } \\
(\%)\end{array}$ & $\begin{array}{c}\text { Agree } \\
(\%)\end{array}$ & $\begin{array}{c}\text { Neutral } \\
(\%)\end{array}$ & $\begin{array}{c}\text { Disagree } \\
(\%)\end{array}$ & $\begin{array}{c}\text { Strongly } \\
\text { disagree } \\
(\%)\end{array}$ \\
\hline $\begin{array}{l}\text { 1. Primary school classroom teachers have a duty } \\
\text { to understand pupils' cultural backgrounds. }\end{array}$ & 16.7 & 50.0 & 28.3 & 5.0 & 0.0 \\
\hline $\begin{array}{l}\text { 2. Good primary school classroom teachers must } \\
\text { understand the cultural differences between pupils. }\end{array}$ & 20.8 & 39.2 & 25.8 & 11.7 & 2.5 \\
\hline $\begin{array}{l}\text { 3. I should understand the diversity of their } \\
\text { cultural backgrounds. }\end{array}$ & 12.2 & 34.7 & 35.7 & 13.3 & 4.1 \\
\hline $\begin{array}{l}\text { 4. Regardless of cultural backgrounds, all pupils } \\
\text { should be aware of the cultural diversity. }\end{array}$ & 4.2 & 45.0 & 22.5 & 18.3 & 10.0 \\
\hline $\begin{array}{l}\text { 5. Encouraging pupils to be proud of their culture } \\
\text { is not the responsibility of classroom teachers. }\end{array}$ & 11.7 & 39.2 & 23.3 & 20.8 & 5.0 \\
\hline $\begin{array}{l}\text { 6. To satisfy the pupils from different cultural } \\
\text { backgrounds, classroom teachers should adopt } \\
\text { different class management strategies. }\end{array}$ & 24.0 & 39.3 & 19.9 & 14.8 & 2.0 \\
\hline 7. All pupils must speak Mandarin in the class. & 41.1 & 47.5 & 8.3 & 3.1 & 0.0 \\
\hline $\begin{array}{l}\text { 8. Teaching pupils multicultural knowledge will } \\
\text { only lead to conflict in the class. }\end{array}$ & 0.8 & 14.2 & 5.0 & 56.7 & 23.3 \\
\hline $\begin{array}{l}\text { 9. Educating pupils to respect different cultures is } \\
\text { classroom teachers' responsibility. }\end{array}$ & 31.3 & 42.8 & 15.2 & 9.2 & 1.5 \\
\hline $\begin{array}{l}\text { 10. I will invite the pupils' families from different } \\
\text { cultural backgrounds to participate in school } \\
\text { activities. }\end{array}$ & 29.2 & 54.2 & 14.1 & 2.5 & 0.0 \\
\hline
\end{tabular}

Many a primary school classroom teacher reckons that they have the responsibility to understand pupils' cultural backgrounds $(66.7 \%)$ and good primary school teachers must acquaint themselves with pupils' cultural differences $(60 \%)$. Accordingly, they have realized the importance of students' different cultural backgrounds. In contrast, only less than half of teachers agree pupils should also be aware of cultural diversity. Hence, it can be concluded that a few primary school classroom teachers attach great significance to their own multicultural literacy and relevant knowledge which is the requisite to implement multicultural education while they lack a distinct recognition of the content and purpose of multicultural education. What's more, although $74.1 \%$ of primary school classroom teachers regard educating pupils to respect different cultures as their responsibility, only $25.8 \%$ insist that it is also their obligation to encourage students to take pride in their own culture. By this token, primary school classroom teachers pay more attention to helping students respect other cultures; they ignore the cultivation of students' own cultural self-confidence yet. In addition, $80 \%$ of teachers do not consider students' multicultural knowledge will only lead to class conflict. Namely, they tend to impart pupils' multicultural knowledge. On concrete operation of multicultural education, $46.9 \%$ of teachers express that they would encourage more exchanges of students from different cultural backgrounds. $63.3 \%$ hold that to satisfy the pupils from different cultural backgrounds, classroom teachers should adopt different class management strategies. $83.4 \%$ claim that they will invite the pupils' families from different cultural backgrounds to participate in school activities.

The vast majority of primary school classroom teachers $(88.6 \%)$ deem that all pupils in the class must speak Mandarin. Through further interview, teachers indicate they do not exclude the various dialects in the class. They consider pupils can utilize dialects when chatting privately but not in public occasions so as to avoid communication barriers.

Survey results also manifest that the neutral proportions in question 1-10 are $28.3 \%, 25.8 \%, 35.7 \%$, $22.5 \%, 23.3 \%, 19.9 \%, 8.3 \%, 15.2 \%$ and $14.1 \%$ respectively. 
Weiju Zhao \& Ling Liu

\subsection{Variance Analysis of Primary School Classroom Teachers' Attitudes toward Multi-Culture and Multicultural Education}

Table4. T test of primary school classroom teachers' attitudes toward multi-culture

\begin{tabular}{|c|c|c|c|c|}
\hline Variable & \multicolumn{2}{|c|}{ Value } & Standard error & T \\
\hline \multirow{2}{*}{ Gender } & Male & Female & .933 & \multirow{2}{*}{1.015} \\
\cline { 2 - 3 } & $16.85 \pm 4.86$ & $15.91 \pm 5.28$ & & \multirow{2}{*}{$-2.913^{* *}$} \\
\cline { 2 - 3 } & Local & Nonlocal & .936 & \\
\hline \multirow{2}{*}{ Local identity } & $15.34 \pm 4.81$ & $18.07 \pm 5.16$ & & $2.727^{* *}$ \\
\cline { 2 - 3 } & Urban & Rural & .924 & \\
\hline
\end{tabular}

Note: $* p<0.05, * * p<0.01, * * * p<0.001$, the same below.

Table5. Variance analysis and multiple comparisons of primary school classroom teachers' attitudes toward multi-culture

\begin{tabular}{|c|c|c|c|c|c|c|c|}
\hline Variable & \multicolumn{6}{|c|}{ Value } & $\mathrm{F}$ \\
\hline \multirow[t]{2}{*}{ Age } & $<25$ & \multirow{2}{*}{$\frac{26-35}{1837^{b}}$} & & & $46-55$ & $>55$ & \multirow[t]{2}{*}{$24.085 * * *$} \\
\hline & $21.4^{\mathrm{a}}$ & & & & $13^{\mathrm{d}}$ & $9.7^{\mathrm{e}}$ & \\
\hline \multirow[t]{2}{*}{ Teaching years } & $<2$ & $2-5$ & $6-10$ & $11-15$ & $16-20$ & $>20$ & \multirow[t]{2}{*}{$14.108 * * *$} \\
\hline & $19.83^{b}$ & $21.5^{\mathrm{a}}$ & $17.81^{b}$ & $16.56^{\mathrm{b}}$ & $13.44^{\mathrm{c}}$ & $10.93^{\mathrm{c}}$ & \\
\hline \multirow[t]{2}{*}{ Education background } & \multicolumn{2}{|c|}{$\begin{array}{c}\text { Secondary normal } \\
\text { school }\end{array}$} & Associate & \multicolumn{2}{|c|}{ Bachelor } & Master & \multirow[t]{2}{*}{$18.246^{* * *}$} \\
\hline & \multicolumn{2}{|c|}{$11.92^{\mathrm{c}}$} & $15.43^{\mathrm{b}}$ & \multicolumn{2}{|c|}{$18.59^{\mathrm{a}}$} & $20.56^{\mathrm{a}}$ & \\
\hline
\end{tabular}

Note: The same line does not contain the same letter that exists significant difference at 0.05 level, the same below.

Table6. T test of primary school classroom teachers' attitudes toward multicultural education

\begin{tabular}{|c|c|c|c|c|}
\hline Variable & \multicolumn{2}{|c|}{ Value } & Standard error & $\mathrm{T}$ \\
\hline \multirow{2}{*}{ Gender } & Male & Female & 1.664 & \multirow{2}{*}{.637} \\
\cline { 2 - 3 } & $26.69 \pm 8.83$ & $25.63 \pm 9.29$ & & \multirow{2}{*}{$-3.473^{* *}$} \\
\cline { 2 - 3 } Local identity & Local & Nonlocal & 1.642 & \\
\hline \multirow{2}{*}{ School position } & $24.03 \pm 8.09$ & $29.73 \pm 9.58$ & & $3.212^{* *}$ \\
\cline { 2 - 3 } & Urban & Rural & 1.626 & \\
\hline
\end{tabular}

Table7. Variance analysis and multiple comparisons of primary school classroom teachers' attitudes toward multicultural education

\begin{tabular}{|c|c|c|c|c|c|c|c|}
\hline Variable & \multicolumn{6}{|c|}{ Value } & $\mathrm{F}$ \\
\hline \multirow[t]{2}{*}{ Age } & \multirow{2}{*}{\multicolumn{2}{|c|}{$\frac{<25}{358^{a}}$}} & 26-35 & $36-45$ & $46-55$ & $>55$ & \multirow[t]{2}{*}{$28.155^{* * * *}$} \\
\hline & & & $30^{b}$ & & $.74^{\mathrm{d}}$ & $14.9^{\mathrm{e}}$ & \\
\hline \multirow[t]{2}{*}{ Teaching years } & $<2$ & $2-5$ & $6-10$ & $11-15$ & $16-20$ & $>20$ & \multirow[t]{2}{*}{$18.730 * * *$} \\
\hline & $33.67^{b}$ & $36.43^{\mathrm{a}}$ & $28.24^{\mathrm{bc}}$ & $26.11^{\mathrm{c}}$ & $20.56^{\mathrm{d}}$ & $16.13^{\mathrm{e}}$ & \\
\hline \multirow[t]{2}{*}{ Education background } & \multicolumn{2}{|c|}{$\begin{array}{c}\text { Secondary normal } \\
\text { school }\end{array}$} & Associate & \multicolumn{2}{|c|}{ Bachelor } & Master & \multirow[t]{2}{*}{$16.345^{* * *}$} \\
\hline & \multicolumn{2}{|c|}{$19.54^{b}$} & $23.65^{b}$ & \multicolumn{2}{|c|}{$30.41^{\mathrm{a}}$} & $33.56^{\mathrm{a}}$ & \\
\hline
\end{tabular}

Based on Table 4 and 6 , there is no significant gender difference in primary school classroom teachers' attitudes toward multi-culture and multicultural education. But in the dimension of local identity and school position, primary school head teacher' scores show significant differences. Nonlocal primary school classroom teachers who work in Nantong get higher scores than local teachers. Urban primary school classroom teachers get higher scores than rural school teachers.

By variance analysis and multiple comparisons, it can be concluded that the variable of age, teaching years and education background have significant difference result on primary school classroom teachers' attitudes toward multi-culture and multicultural education.

(1) The older teachers are; the lower scores they get.

(2) Teachers with 2-5 teaching years attain highest scores, followed by less than 2 years, then 6-10 years, 11-15 years, 16 to 20 years and more than 20 years. In general, with the growth of seniority, classroom teachers' attitudes gradually weaken. Data also shows that there is no significant difference among less than 2 years seniority, 6-10 and 11-15 years seniority. 
(3) The higher education level teachers have; the higher scores they get. The data illustrates there is significant difference between secondary normal school degree and associate degree. While the difference between the bachelor and the master is not significant.

\section{CONCluSion AND RECOMMENDATIONS}

\subsection{Conclusion}

Most of the primary school classroom teachers hold positive attitudes toward multi-culture and multicultural education, while some are fuzzy and few are negative.

The attitudes of nonlocal primary school classroom teachers who work in Nantong are more positive than that of local teachers. Urban primary school classroom teachers' attitudes are more positive than rural school teachers'.

The younger primary school classroom teachers are, the more positive attitudes they hold. There are significant differences in primary school teachers' attitude toward multi-culture as well as multicultural education in age influence factor. Teachers with 2-5 years teaching years have most positive attitudes. Approximately, with the growth of seniority, classroom teachers' perceptions on multiculturalism gradually weaken. There are significant differences in primary school teachers' attitude toward multi-culture as well as multicultural education in teaching years influence factor. The higher education backgrounds primary school classroom teachers own, the more positive attitudes they hold.

\subsection{Recommendations}

(1) Indubitably, primary school classroom teachers are the primary subject of multicultural education and their attitudes toward multi-culture and multicultural education is the key to primary school multicultural education. Consequently, cultivating primary school classroom teachers' active attitudes are intensively significant.

(2) Teacher education institution is supposed to set up professional multicultural curriculum and penetrate multicultural concept into the entire primary school teachers' training project (Wang, 2012) for raising pre-service primary school teachers' personal awareness about different categories of prospective elementary school teachers of individual differences, and how these differences enhances or hinders the ways students and teachers generally interact with each other (Jared, 2010) .

(3) Educational administrative department and primary schools are supposed to increase the recruiting number of primary school classroom teacher candidates from the field to construct a more diversified school and class atmosphere. Meanwhile, educational administrative department should develop relevant policies to promote rural primary school classroom teachers to teach in city, so that they can have access to more pupils from diverse cultural backgrounds, observing and studying pluralistic cultural educational concept and methods.

(4) Teacher education institution, educational administrative department and primary schools should implement targeted and personalized multicultural training according to teachers' age, teaching years and education background; especially strengthen the training for the teachers who are older, with longer teaching years and attain lower educational levels.

\section{REFERENCES}

[1] Banks, J. A., McGee-Banks, C., Cortes, C., Hahn, C. L., Merryfield, M., Moodley, K., et al., Democracy and diversity: Principles and concepts for educating citizens in a global age. Seattle: Center for Multicultural Educatio, College of Education, University of Washington. (2005).

[2] Tian, Y., Macao Teachers' Attitudes towards Multicultural Education. Global Education, 7, 41-48 (2002).

[3] Wang,Y.L., Preparing Culturally Responsive Teachers: The Issue and Challenge of Multicultural Teacher Education. Global Education, 2, 12-19 (2012).

[4] Jared, K., Cross Cultural Competence in Pre-service Teachers through Multicultural Education Experiences. Early Childhood Education. 38, 197-204 (2010). 
AUTHORS' BIOGRAPHY

Weiju Zhao (1974-) female, associate professor of Nantong university, graduate tutor. She is interested in primary school education and teacher education.

Ling Liu (1992-) female, graduate in College of Education Science, Nantong University. Her major is primary school education. 